\begin{tabular}{|ll|}
\hline Received & $: 25$ March 2019 \\
Revised & $:$ 1 September 2019 \\
Accepted & $:$ 13 September 2019 \\
Published & $: 27$ Desember 2019 \\
\hline
\end{tabular}

\title{
Digital Text Book: A State of The Art Learning Resource to Increase Learner's Achievement
}

\author{
${ }^{1}$ Maria Puspa Sari ${ }^{1, a)}$, Armi Antasari ${ }^{1, b)}$, \\ ${ }^{2}$ Akamigas Polytechnic of Palembang, Indonesia \\ E-mail: ${ }^{\text {a) }}$ mariapuspasari@pap.ac.id, ${ }^{\text {b) }}$ armi@pap.ac.id
}

\begin{abstract}
Digital textbook is an electronic version of printed books which has been popular in education. Several related studies had confirmed the advantages of using digital textbook for ESL learners. This study was conducted to explore the effectiveness of digital textbook in increasing learners' proficiency in English as well as the learners' and teachers attitude towards digital textbook. The quantitative study with fifty seven participants was a true experimental research which applied pretest-posttest control group design. Having two groups of participants (experimental and control), this research was conducted by selecting the participants randomly, administering pretest, giving treatment, administering posttest, analyzing the data and interpreting the results. This research found that even though data was not normally distributed, the data still had the same variances. Therefore, the independent t-test in this research used Wilcoxon Signed Rank Test. The results discovered that the $t$ value was 0.030 which was lower than 0.050. It indicated that the treatment was significantly effective in this research. In other words, this research revealed that digital textbook had contributed positively to the learners' English achievement as it was seen from the better performance of the experimental group than the control group. Then, the qualitative study of this research interviewed three participants and one lecturer. Most of the participants shared the same opinion that digital textbook had positive contribution for their ESL class.
\end{abstract}

Keywords: digital textbook, English proficiency, ESL Learners

\begin{abstract}
Abstrak
Buku teks digital adalah versi elektronik dari buku cetak yang sudah terkenal di dalam dunia pendidikan. Beberapa studi terkait telah mengonfirmasi keuntungan menggunakan buku teks digital untuk pelajar ESL. Penelitian ini dilakukan untuk mengeksplorasi efektivitas buku teks digital dalam meningkatkan kemahiran peserta didik dalam bahasa Inggris serta sikap peserta didik dan guru terhadap buku teks digital. Penelitian ini merupakan penelitian kuantitatif dengan peserta yang berjumlah lima puluh tujuh dan merupakan penelitian eksperimental yang benar dalam menerapkan desain kelompok kontrol pretest-posttest. Memiliki dua kelompok peserta (eksperimental dan kontrol), penelitian ini dilakukan dengan memilih peserta secara
\end{abstract}


acak, memberikan pretest, memberikan perawatan, mengelola posttest, menganalisis data dan menginterpretasikan hasil. Penelitian ini menemukan bahwa meskipun data tidak terdistribusi secara normal, data tersebut masih memiliki varian yang sama. Oleh karena itu, uji-t independen dalam penelitian ini menggunakan Wilcoxon Signed Rank Test. Hasil menemukan bahwa nilai t adalah 0,030 yang lebih rendah dari 0,050. Itu menunjukkan bahwa pengobatan secara signifikan efektif dalam penelitian ini. Dengan kata lain, penelitian ini mengungkapkan bahwa buku teks digital telah memberikan kontribusi positif terhadap prestasi bahasa Inggris peserta didik karena dilihat dari kinerja yang lebih baik dari kelompok eksperimen daripada kelompok kontrol. Kemudian, studi kualitatif dari penelitian ini mewawancarai tiga peserta dan satu dosen. Sebagian besar peserta berbagi pendapat yang sama bahwa buku teks digital memiliki kontribusi positif untuk kelas ESL mereka.

Kata kunci: buku teks digital, kemahiran bahasa Inggris, Pembelajar ESL

\section{PENDAHULUAN}

Buku teks telah membantu peserta didik dan guru di kelas; itu menyediakan satu set konten terstruktur yang dilengkapi dengan latihan dan tes dan juga menghemat waktu dan upaya guru untuk menyiapkan bahan ajar (Charalambous, 2011; Richards, 2015). Seiring dengan perkembangan teknologi dan perubahan besar dalam bidang pendidikan terutama dalam Pengajaran Bahasa Inggris (ELT), perkembangan teknologi telah menghasilkan pengembangan buku teks. Keberadaan e-book yang merupakan versi elektronik dari buku kertas telah merangsang pengembangan buku teks. Beberapa penerbit telah unggul dalam pekerjaan mereka dengan juga melengkapi buku teks mereka dengan versi interaktif dari buku teks mereka.

Buku teks digital atau kadang-kadang disebut sebagai buku teks interaktif mengacu pada versi elektronik buku teks kertas yang dapat dibuka di komputer, laptop, ponsel atau tablet (Blazer, 2013). Beberapa buku teks interaktif hanyalah versi PDF dari buku kertas atau biasanya dikenal sebagai e-book, dalam bentuk aplikasi yang dikembangkan oleh platform seperti Smartbok dan Keterampilan, dan versi digital buku teks kertas yang dilengkapi dengan CD-ROM untuk menginstal aplikasi buku digital (Blazer, 2013; Murray \& Perez, 2011; Ødegård, 2017). Dengan demikian, penelitian ini akan mengeksplorasi efektivitas buku teks interaktif yang diinstal dari CD-ROM dari buku kertas. Buku teks interaktif semacam ini yang diinstal dari CD-ROM berisi materi seperti di buku kertas. Versi digital ini memungkinkan peserta didik untuk mendengarkan audio, menonton video, bermain game, kuis, melihat kamus dan mendapatkan informasi bahasa hanya dengan mengeklik opsi di layar (Mitsikopoulou, 
2014, hlm. 411; Murray \& Perez, 2011). Beberapa peneliti telah mengungkapkan beberapa hasil dari studi mereka yang berfokus pada penggunaan buku teks digital di ELT. Bikowski dan Casal (2018) menemukan bahwa semua peserta merasa sangat puas dengan buku teks digital dan sangat dianjurkan untuk pembelajaran bahasa Inggris. Ada beberapa kelebihan dari buku teks digital. Pertama, buku teks digital dapat meningkatkan fleksibilitas dan kontrol pelajar, motivasi, minat, pengalaman belajar dan kenyamanan (Bikowski \& Casal, 2018). Dengan buku teks interaktif diinstal di laptop atau komputer mereka, peserta didik juga dapat menghemat waktu belajar dan upaya mereka untuk membawa buku kertas (Blazer, 2013). Di sisi lain, Blazer (2013) juga menjelaskan bahwa buku teks digital tidak efektif untuk membaca karena pembelajar menemukan lebih lambat saat membaca. Juga, buku teks digital dapat mempertahankan peserta didik dalam fokus pada konten buku mereka terutama untuk informasi detail.

Dalam hal mengeksplorasi efek buku teks digital, sebagian besar penelitian terbaru berfokus pada penentuan perspektif peserta didik dan guru atas penggunaan buku teks digital tanpa mengukur seberapa efektif buku teks digital untuk kemahiran peserta didik (Murray \& Perez, 11), hal. 52). Untuk mengisi kesenjangan ini, penelitian ini, bertujuan untuk mengeksplorasi seberapa efektif buku teks digital untuk meningkatkan kemahiran bahasa Inggris peserta didik EFL serta tanggapan dari peserta didik dan guru setelah menggunakan buku teks digital. Alasan mengapa penelitian ini membawa misi penting adalah karena sebagian besar negara maju telah menjadikan buku teks digital sebagai program pendidikan nasional mereka sementara, di Indonesia, buku teks digital masih dianggap 'langka'. Ini tidak banyak digunakan di sekolah. Hanya beberapa sekolah swasta internasional atau superior yang menggunakan bentuk teknologi ini.

Dalam penelitian ini, peran bentuk buku teks terbaru dieksplorasi. Ini diprakarsai oleh potensi keuntungan bagi pelajar, guru dan institusi. Buku teks sebagai salah satu sumber utama dalam pembelajaran memegang peranan yang sangat penting.

Buku teks adalah bagian penting dari kursus. Ini adalah salah satu sumber daya utama bagi peserta didik. Buku teks adalah buku standar yang digunakan dalam kursus, kelas, perguruan tinggi atau sekolah sebagai sumber informasi utama bagi guru dan peserta didik (Graves, 2000; Hornby, 2006; Richards, 2015). Buku teks standar biasanya mencakup silabus, instruksi, berbagai sumber belajar, model bahasa dan kualitas yang 
terjaga (Richards, 2015). Dengan konten tersebut, ini membantu guru dalam mengajar dan bahkan memberi manfaat bagi guru baru karena buku teks biasanya dalam bentuk materi terstruktur yang menawarkan beberapa orientasi dan bimbingan pengajaran (Gak, 2011). Dalam ELT, buku teks bahkan bermain sebagai jendela negara berbahasa Inggris sebagai buku teks EFL termasuk budaya model bahasa barat dan otentik untuk pelajar (Radić-Bojanić \& Topalov, 2016). Sejauh ini, desain dan konten buku teks telah dikembangkan untuk mengimbangi kemajuan teknologi dan kehidupan modern pelajar.

Saat ini, bentuk buku teks menjadi lebih modern dengan memiliki versi elektronik atau e-book dan bahkan buku teks dapat ditemukan dalam bentuk digital atau biasanya disebut sebagai buku teks digital atau interaktif. Jika e-book merujuk ke versi elektronik yang persis sama dengan versi kertas, buku teks digital mengacu pada sumber belajar elektronik yang memungkinkan pengguna untuk mengakses audio, video, informasi bahasa dan semua jenis konten interaktif hanya dengan mengklik tombol (Fernandes, 20111, p. 3194; Murray \& Perez, 2011).

Inisiatif buku teks digital telah dimulai di AS selama dua dekade dan ini dimulai dari CD dan sekarang buku teks digital dapat diakses melalui online (Fernandes, 2012). Banyak platform menghasilkan buku teks interaktif dengan berbagai tujuan, konten dan fitur interaktif. Ada beberapa kelebihan dari buku teks versi baru ini. Pertama-tama, ini ramah lingkungan karena tidak menggunakan kertas sebagai bahan, jadi harganya lebih murah daripada kertas dan mengurangi upaya peserta didik untuk membawa tas berat ke perguruan tinggi (Blazer, 2013; Fernandes, 2012, hal. 50). Fitur interaktifnya yang memungkinkan pelajar untuk menonton video, mendengarkan audio, dll. Dapat meningkatkan pengalaman belajar (Blazer, 2013; Bikowski \& Casal, 2018). Kemudian, itu juga dapat meningkatkan keterlibatan, kepuasan, partisipasi, dan kenyamanan peserta didik dalam belajar serta melek teknologi mereka (Bikowski \& Casal, 2018). Oleh karena itu, tidak mengherankan ketika banyak negara maju menganggap buku digital sebagai tren baru dalam pendidikan dan memutuskan untuk membuat program nasional untuk mengakomodasi tren ini.

Saat ini, ada beberapa format buku teks digital atau interaktif yang banyak dikenal terutama di negara-negara maju. Pada awal dekade terakhir, bentuk pertama buku elektronik muncul dalam bentuk dokumen pdf yang merupakan bentuk pindaian dari versi cetak (Mitsikopoulou, 2014). Beberapa tahun terakhir, bentuk buku teks sudah 
lebih modern. Bentuk baru buku teks adalah aplikasi buku teks digital yang harus diinstal dari CD ROM buku kertas. Penerbit menyelesaikan buku cetak mereka dengan $\mathrm{CD}$ atau DVD yang memungkinkan pengguna mereka untuk menginstal aplikasi buku teks digital mereka (Odegard, 2017). Akhirnya, versi terbaru dari buku teks adalah dalam bentuk aplikasi di komputer, tablet bahkan smartphone yang dapat diunduh dan digunakan baik offline maupun online (Bikowski \& Casal, 2018; Fernandes, 2012; Odegard, 2017).

Tren baru dalam pendidikan ini terutama pengajaran bahasa Inggris telah menarik banyak penerbit dan platform untuk mengembangkan produk mereka dan bersaing di seluruh dunia. Menurut Fernandes (2012, p. 3193), pada awal tren ini, Amerika Serikat mulai pada dekade terakhir dengan memfasilitasi sekolah dengan komputer dan internet. Sejak itu, buku teks digital menjadi lebih populer karena menawarkan potensi keuntungan dan keuntungan. Fernandes (2011) membandingkan beberapa buku teks digital dari berbagai penerbit dan platform seperti Apple iBooks, Studi Barnes \& Noble NOOK, CafeScribe, CengageMindTap, CengageYouBook, CourseSmart, DynamicBooks, Flat World Knowledge (MIYO, Ingram Vitalsource, McGraw-Hill Buat dan Hubungkan, Pageburst, Pearson MyLab, Wikibooks, Xplana, dan eReader. Semua buku teks digital tersebut dapat diakses secara online dan offline melalui komputer, tablet, dan smartphone, buku teks digital mereka mencakup fitur-fitur dasar seperti penyorotan, pencatatan, tag warna dan bookmark. Namun, mereka memiliki fitur unik yang berbeda sebagai strategi mereka untuk menarik pengguna seperti Apple iBooks dengan animasi 3D, video dan ilustrasi interaktifnya, Studi Barnes \& Noble NOOK dengan tampilan dua buku, panduan dan kamus instruktur, CafeScribe dengan komunitas bacanya, DynamicBooks dengan online-nya tes, instruktur dan animasi, dan Pearson MyLab dengan text-to-speech dan integrasi LMS-nya. buku teks onic telah sampai pada tahap buku teks digital atau interaktif yang tersedia baik online maupun offline. Buku-buku teks digital tersebut dapat diakses dengan hanya membeli aplikasi mereka secara online, lisensi melalui kartu kredit dan menginstal aplikasi mereka dari DVD atau CD ROM.

Sebagai kesimpulan, buku teks telah ditemukan bermanfaat bagi peserta didik dalam belajar. Beberapa pelajar dan guru juga sepakat bahwa teknologi terbaru ini menyenangkan dan bermanfaat. Oleh karena itu, penelitian ini mengeksplorasi 
efektivitas buku teks digital dan bagaimana peserta didik dan guru merespons teknologi ini.

\section{METODE PENELITIAN}

Studi pendahuluan ini adalah studi eksperimental yang bertujuan untuk menentukan efektivitas buku teks digital pada kinerja Bahasa Inggris peserta didik dan sikap siswa dan guru terhadap buku teks digital. Populasi penelitian ini adalah mahasiswa Politeknik Akamigas Palembang. Buku teks digital yang digunakan dalam penelitian ini adalah SpeakOut Edisi Kedua yang diterbitkan oleh Pearson Longman. Buku ini diterbitkan dalam dua versi; buku cetak dan digital. Buku teks digital yang disebut ActiveTeach harus diinstal dari CD ROM. Buku teks digital ini memiliki beberapa fitur seperti jawaban untuk latihan, audio, video terintegrasi, pintasan ke halaman yang relevan dari pelajaran tata bahasa dan gambar dengan kosa kata, lembar kerja tambahan, tes, permainan bahasa Inggris, keyboard, keyboard fonetik, stopwatch, dan papan skor (Carr \& Maguire, 2012). Ada dua instrumen yang digunakan dalam penelitian ini; tes bahasa Inggris dan wawancara. Dari tes ini, akan ditemukan apakah tingkat kemahiran bahasa Inggris peserta didik meningkat atau tidak setelah perawatan dan wawancara akan mengetahui apakah siswa dan guru mereka menemukan dampak positif dari perawatan.

\section{Desain Penelitian}

Karena tujuan penelitian ini adalah untuk mengetahui apakah penggunaan buku teks digital efektif untuk meningkatkan kemahiran berbahasa Inggris peserta didik, penelitian ini dilakukan dengan melakukan percobaan pada dua kelompok peserta.

Penelitian ini menggunakan desain eksperimen sejati menggunakan desain kelompok kontrol pretest-posttest. Penelitian ini dilakukan dalam beberapa tahap. Yang pertama adalah seleksi peserta; ada dua kelas yang dipilih secara acak sebagai peserta penelitian ini dan mereka ditugaskan sebagai kelompok eksperimen dan kontrol. Kelompok eksperimen menerima perlakuan, yaitu belajar menggunakan buku teks digital yang dipilih. Kelompok itu diajar oleh seorang dosen dalam 16 pertemuan termasuk pre-test dan post-test. Setelah perawatan selesai, data yang dikumpulkan dari nilai pre-test dan post-test peserta dihitung dan dianalisis menggunakan uji-t. Dalam menganalisis skor 
peserta, pertama, uji-t berpasangan dilakukan untuk mengetahui apakah skor posttest kelompok eksperimen lebih baik daripada skor pretest mereka. Setelah itu, uji-t independen dilakukan untuk membandingkan kinerja pasca-tes dari kelompok eksperimen dan kontrol. Ini untuk mengetahui apakah buku teks digital efektif untuk meningkatkan prestasi bahasa Inggris peserta didik.

Setelah menggunakan buku teks digital, beberapa peserta kelompok eksperimen dan dosen mereka diwawancarai menanyakan pendapat dan pandangan mereka terhadap buku teks digital. Setelah wawancara selesai, hasil dari wawancara akan ditranskripsikan dan ditafsirkan.

\section{Peserta}

Penelitian ini melibatkan lima puluh tujuh peserta di sebuah perguruan tinggi swasta di Palembang. Mereka semua adalah pelajar bahasa Inggris di sebuah perguruan tinggi teknik, Politeknik Akamigas Palembang. Pada saat perawatan, mereka berada di tahun pertama belajar. Peserta ini dipilih secara acak sebagai desain eksperimental yang benar membutuhkan metode pengambilan sampel acak. Mereka kemudian ditugaskan ke dalam dua kelompok; kelompok eksperimen dan kontrol. Kelompok eksperimen terdiri dari 32 peserta sedangkan kelompok kontrol memiliki 25 peserta.

\section{Koleksi Data dan Analisis}

Data dikumpulkan dari pretest dan posttest dalam penelitian ini. Setelah mengumpulkan data, analisis data dilakukan. Analisis data dalam penelitian ini adalah uji normalitas, uji homogenitas, paired sample t-test dan independent t-test. Pada awalnya, uji normalitas dilakukan untuk mengetahui apakah data itu normal. Setelah itu uji homogenitas juga dilakukan untuk mengetahui apakah data memiliki varian yang sama. Kemudian, uji-t berpasangan dilakukan untuk mengetahui apakah ada perbedaan yang signifikan antara pretest dan posttest pada kelompok eksperimen. Akhirnya, uji-t independen dilakukan untuk membandingkan kinerja antara kelompok eksperimen dan kontrol.

Wawancara dilakukan setelah perawatan selesai dan ditranskripsi serta ditafsirkan. Jawaban dari wawancara akan menjawab jika buku teks digital lebih disukai. Selanjutnya, untuk membuktikan kepercayaan wawancara ini, metode 
pengecekan anggota digunakan setelah hasil penelitian dianalisis.

Penelitian ini juga melibatkan dua peneliti; ketua dan anggota peneliti. Kedua peneliti adalah dosen dalam pengajaran bahasa perguruan tinggi. Kepala peneliti bertanggung jawab untuk merancang penelitian, menentukan pemilihan peserta, melakukan perawatan dan menafsirkan hasil penelitian. Sementara itu, anggota bertanggung jawab untuk melakukan pretest dan posttest, menganalisis data dan menyajikan data.

\section{HASIL DAN PEMBAHASAN}

Dalam penelitian ini, ada pre-test dan post-test yang diberikan kepada 57 peserta; 32 peserta dalam kelompok eksperimen dan 25 peserta dalam kelompok kontrol. Setelah melakukan tes dan perawatan, ditemukan bahwa kedua kelompok memiliki kinerja yang berbeda. Secara keseluruhan, kelompok eksperimen melakukan pencapaian yang lebih baik daripada kelompok kontrol. Penjelasan detail akan dijelaskan lebih lanjut di bagian berikut.

\section{Grup Eksperimental}

Dalam kelompok eksperimen, 32 peserta mengambil bagian dalam pre-test, perawatan dan post-test. Para peserta ini diminta untuk mengikuti perawatan sampai selesai. Pada pre-test, skor rata-rata adalah 80, skor tertinggi adalah 97 dan skor terendah adalah 64. Setelah melakukan pre-test, para peserta terus mendapatkan perawatan. Perlakuan itu diajarkan bahasa Inggris menggunakan buku teks digital untuk beberapa pertemuan rutin. Ketika pengobatan selesai, para peserta kemudian diberikan post-test. Hasil post-test kemudian dihitung dan peningkatan ditemukan; skor rata-rata adalah 86, skor tertinggi adalah 100 dan terendah adalah 60.

Berdasarkan hasil, dapat disimpulkan bahwa dari pre-test dan post-test mereka, peserta dalam kelompok eksperimen menunjukkan tren positif dengan memiliki peningkatan prestasi.

\section{Grup Kontrol}

Tidak seperti kelompok eksperimen yang terdiri dari 32 peserta, kelompok kontrol hanya memiliki 25 peserta yang mengambil bagian dalam pre-test dan post-test. Pada pre-test, skor rata-rata adalah 77, skor tertinggi adalah 97 dan skor terendah adalah 62. Hasil post-test kemudian dihitung dan peningkatan ditemukan; skor rata-rata adalah 
80, skor tertinggi adalah 92 dan terendah adalah 64.

Berdasarkan hasil, dapat disimpulkan bahwa dari pre-test dan post-test mereka, peserta dalam kelompok kontrol menunjukkan tren positif dengan memiliki peningkatan prestasi. Namun, berdasarkan perhitungan, kelompok eksperimen tampil sedikit lebih baik daripada kelompok kontrol.

Uji Normalitas dan Uji Homogenitas

Tes normalitas diperlukan ketika analisis uji-t akan dilakukan. Itu bertujuan untuk memastikan bahwa data terdistribusi secara normal. Dalam penelitian ini, sebelum menganalisis data untuk mendapatkan uji-t berpasangan dan independen, uji normalitas dilakukan terlebih dahulu. Hasil uji normalitas untuk kelompok eksperimen adalah sebagai berikut:

Table 1. Tests of Normality for Experimental Group

\begin{tabular}{l|l|l|l|l|l|l|l}
\hline \multirow{2}{*}{\begin{tabular}{l} 
Experimenta \\
\cline { 3 - 8 }
\end{tabular}} & \multicolumn{2}{|l|}{ Kolmogorov-Smirnov $^{\text {a }}$} & \multicolumn{2}{l}{ Shapiro-Wilk } \\
\cline { 2 - 7 } & Statistic & df & Sig. & Statistic & df & Sig. \\
\hline \multirow{2}{*}{ Score } & Pretest &, 085 & 32 &, $200^{*}$ &, 970 & 32 &, 495 \\
\cline { 2 - 8 } & Postest &, 197 & 32 &, 003 &, 866 & 32 &, 001 \\
\hline
\end{tabular}

*Ini adalah batas bawah dari signifikansi sejati.

Sebuah. Koreksi Signifikansi Lilliefors

Berdasarkan tabel, nilai signifikan untuk pretest adalah 0,495 dan untuk posttest adalah 0,001. Dengan demikian, data pretest terdistribusi normal, tetapi data posttest sebaliknya. Berikut adalah hasil uji homogenitas untuk kelompok eksperimen:

Tabel 2. Uji Homogenitas Varians

Table 2. Test of Homogeneity of Variance

\begin{tabular}{ll|l|l|l|l}
\hline & $\begin{array}{l}\text { Levene } \\
\text { Statistic }\end{array}$ & $\mathrm{df1}$ & $\mathrm{df2}$ & Sig. \\
\hline Score & Based on Mean & 13,363 & 1 & 62 &, 001 \\
$\begin{array}{l}\text { Based on Median } \\
\text { Based on Median and } \\
\text { with adjusted df } \\
\text { Based on trimmed } \\
\text { mean }\end{array}$ & 5,755 & 1 & 62 &, 019 \\
\hline
\end{tabular}


Tabel tersebut mengungkapkan bahwa nilai signifikan berdasarkan Mean adalah 0,001. Ini berarti bahwa data itu tidak sama.

Kesimpulannya, data percobaan mengungkapkan dua fakta. Yang pertama adalah bahwa data posttest kelompok eksperimen tidak normal walaupun pretestnya normal. Yang kedua adalah bahwa data kelompok eksperimen tidak memiliki varians yang sama.

Data dari kelompok kontrol juga dihitung untuk melihat normalitas dan homogenitasnya. Inilah hasilnya:

Tabel 3. Tes Normalitas untuk Kelompok Kontrol

\begin{tabular}{l|l|l|l|l|l|l|l}
\hline \multirow{2}{*}{} & \multirow{2}{*}{ Control } & \multicolumn{3}{|l|}{ Kolmogorov-Smirnov ${ }^{\text {a }}$} & \multicolumn{3}{l}{ Shapiro-Wilk } \\
\cline { 3 - 8 } & Statistic & df & Sig. & Statistic & df & Sig. \\
\hline \multirow{2}{*}{ Score } & Pretest &, 155 & 25 &, 123 &, 955 & 25 &, 327 \\
\cline { 2 - 8 } & Postest &, 125 & 25 &, $200^{*}$ &, 967 & 25 &, 566 \\
\hline
\end{tabular}

*. Ini adalah batas bawah dari signifikansi sejati.

Sebuah. Koreksi Signifikansi Lilliefors

Tabel menampilkan hasil uji normalitas untuk kelompok kontrol yang terdistribusi normal. Itu bisa dilihat dari sig. nilai pretest yaitu 0,327 dan posttest adalah 0,566 . Hasil uji homogenitas adalah sebagai berikut:

Tabel 4. Uji Homogenitas Varians

\begin{tabular}{l|l|l|l|l|l}
\hline \multicolumn{2}{l|}{} & $\begin{array}{l}\text { Levene } \\
\text { Statistic }\end{array}$ & df1 & df2 & Sig. \\
\hline \multirow{2}{*}{ Score } & Based on Mean & 2,084 & 1 & 48 &, 155 \\
\cline { 2 - 6 } & Based on Median & 1,284 & 1 & 48 &, 263 \\
\cline { 2 - 6 } & $\begin{array}{l}\text { Based on Median and } \\
\text { with adjusted df }\end{array}$ & 1,284 & 1 & 42,123 &, 264 \\
\cline { 2 - 6 } & $\begin{array}{l}\text { Based on trimmed } \\
\text { mean }\end{array}$ & 2,037 & 1 & 48 &, 160 \\
\hline
\end{tabular}

Berdasarkan tabel, data kelompok kontrol memiliki varian yang sama karena nilainya 0,155 lebih tinggi dari tingkat signifikansi 0,05 . Dengan demikian, dapat dikatakan bahwa data kelompok kontrol terdistribusi normal dan memiliki varian yang sama. 
Kesimpulannya, di antara semua data dari dua kelompok, data dari kelompok eksperimen tidak normal dan tidak memiliki varian yang sama. Namun, acaranya harus berlanjut. Analisis data akan tetap berjalan dengan menggunakan uji nonparametrik yang tidak memerlukan distribusi normal dan homogenitas data (Kaur dan Kumar, 2015; Sprent dan Smeeton, 2001)

Perbedaan Kemampuan Bahasa Inggris antara Kelas Buku Teks Digital dan Non-Digital

Dalam fase ini, ada dua analisis data yang dilakukan; paired sample t-test dan independent sample t-test. Uji sampel berpasangan adalah untuk mengungkapkan efektivitas jika pengobatan dalam kelompok eksperimen efektif sedangkan uji-t independen adalah untuk mengungkapkan perbedaan antara dua kelompok yang berbeda yaitu kelompok eksperimen dan kelompok kontrol.

Untuk melakukan uji sampel berpasangan, uji normalitas dilakukan sebelum dan hasilnya adalah data tidak terdistribusi secara normal. Oleh karena itu, dalam analisis ini, uji non-parametrik dilakukan. Sementara uji parametrik memerlukan distribusi normal dan varians yang sama, uji non-parametrik tidak bergantung pada normalitas dan homogenitas data (Kaur dan Kumar, p. 339, 2015).

Dalam penelitian ini, uji sampel berpasangan menggunakan Wilcoxon Sign Rank Test yang dihitung oleh SPSS. Hasil tes adalah sebagai berikut:

Tabel 5. Peringkat

\begin{tabular}{l|l|l|l}
\hline & N & Mean Rank & Sum of Ranks \\
\hline $\begin{array}{l}\text { Negative } \\
\text { Ranks }\end{array}$ & $0^{\mathrm{a}}$ &, 00 &, 00 \\
\hline Positive Ranks & $64^{\mathrm{b}}$ & 32,50 & 2080,00 \\
\hline Ties & $0^{\mathrm{c}}$ & & \\
\hline Total & 64 & & \\
\hline
\end{tabular}

Sebuah. Skor <Eksperimental

Nilai> Eksperimental

Nilai $=$ Eksperimental

Tabel tersebut mengungkapkan bahwa semua peserta dalam kelompok eksperimen 
menunjukkan peningkatan positif dalam prestasi bahasa Inggris mereka. Hal itu dapat dilihat dari jumlah peringkat positif yaitu 64. Kemudian hasil uji Wilcoxon adalah:

Table 5. Test Statistics ${ }^{\mathrm{a}}$

\begin{tabular}{l|l}
\hline & $\begin{array}{l}\text { Score } \\
\text { Experimental }\end{array}$ \\
\hline $\mathrm{Z}$ & $-6,956^{\mathrm{b}}$ \\
\hline Asymp. Sig. (2- &, 000 \\
tailed) & \\
\hline a. Wilcoxon Signed Ranks Test \\
b. Based on negative ranks.
\end{tabular}

Berdasarkan hasil analisis, sig. Nilai (2-tailed) adalah 0,000 yang berada di bawah tingkat signifikansi 0,05. Ini menunjukkan bahwa ada perbedaan yang signifikan secara statistik pada kelompok eksperimen. Oleh karena itu, perawatan dalam kelompok ini dianggap berhasil atau secara signifikan efektif dalam meningkatkan skor peserta.

Setelah membandingkan skor pre-test dan post-test dari kelompok eksperimen, analisis data dilanjutkan untuk menghitung perbedaan skor post-test antara kelompok eksperimen dan kontrol. Hasil analisis adalah sebagai berikut:

Table 6. Ranks

\begin{tabular}{l|l|l|l|l}
\hline & Group & N & Mean Rank & $\begin{array}{l}\text { Sum of } \\
\text { Ranks }\end{array}$ \\
\hline Posttest & Experimental & 32 & 33,22 & 1063,00 \\
\cline { 2 - 5 } & Control & 25 & 23,60 & 590,00 \\
\cline { 2 - 5 } & Total & 57 & & \\
\hline
\end{tabular}

Tabel tersebut menunjukkan bahwa peringkat rata-rata kelompok eksperimen lebih tinggi daripada kelompok kontrol $(33,22>$ 23,60). Jelas terbukti bahwa berdasarkan peringkat rata-rata, kelompok eksperimen berperforma lebih baik. Namun, analisis mendalam masih diperlukan untuk menemukan signifikansinya dan hasilnya adalah: 
Table 7. Test Statistics ${ }^{\mathrm{a}}$

\begin{tabular}{l|l}
\hline & Posttest \\
\hline Mann-Whitney U & 265,000 \\
\hline Wilcoxon W & 590,000 \\
\hline $\mathrm{Z}$ & $-2,173$ \\
\hline $\begin{array}{l}\text { Asymp. Sig. (2- } \\
\text { tailed) }\end{array}$ &, 030 \\
\hline
\end{tabular}

a. Grouping Variable: Group

Hasil uji Mann Whitney U menunjukkan nilai sig. Nilai (2-tailed) adalah 0,30 yang lebih rendah dari 0,050 . Fakta ini menunjukkan bahwa pengobatan secara signifikan efektif dalam penelitian ini. Berdasarkan penjelasan data di atas, dua hasil analisis ditemukan. Berdasarkan uji sampel berpasangan, pengobatan secara signifikan efektif pada kelompok eksperimen karena skor peserta dalam post-test secara keseluruhan lebih tinggi daripada pra-tes mereka. Juga, ketika skor dibandingkan dengan skor dari kelompok kontrol, hasilnya tetap sama yang menunjukkan bahwa pengobatan dalam penelitian ini secara signifikan efektif secara statistik dalam meningkatkan skor peserta.

\section{Sikap Pembelajar dan Guru terhadap Buku Teks Digital}

Setelah menganalisis efektivitas buku teks digital berdasarkan skor peserta, sikap peserta didik dan dosen juga dianalisis dengan melakukan wawancara. Ada tiga peserta dan satu dosen yang diwawancarai. Tiga peserta dipilih berdasarkan skor mereka: tertinggi, sedang dan terendah, sementara dosen hanya satu yang mengajar kelompok eksperimen.

Ada lima pertanyaan untuk setiap orang yang diwawancarai. Wawancara dilakukan setelah perawatan dalam kelompok eksperimen selesai. Berikut adalah hasil wawancara peserta:

Sebuah. Apa pendapat Anda tentang buku teks digital ini untuk kelas ELT Anda?

Peserta 1: Sangat membantu dalam belajar.

Peserta 2: Sangat menyenangkan karena dapat dipelajari dan dipahami dengan mudah 
dan pembelajaran dalam buku itu menyenangkan.

Peserta 3: Menurut saya, buku digital ini sangat menarik sehingga memotivasi saya untuk belajar.

b. Apakah Anda lebih suka buku teks digital daripada kertas? Mengapa?

Peserta 1: Buku teks digital karena tidak monoton dan ada contoh nyata dalam video.

Peserta 2: Saya lebih suka buku cetak karena saya bisa belajar lebih nyaman daripada menggunakan buku teks digital. Saya merasa kesulitan menggunakan laptop karena tidak ada colokan listrik di dekat saya.

Peserta 3: Ya, karena ada daya tarik dalam buku teks digital dan mudah untuk disimpan dibandingkan dengan yang ada di buku teks.

c. Apakah Anda menemui kesulitan dalam menggunakan buku teks digital ini?

Peserta 1: Tidak, saya tidak.

Peserta 2: Ya, saya lakukan karena mungkin saya tidak terbiasa dengan buku teks digital.

Peserta 3: Tidak, saya tidak

d. Bagian mana dari buku teks digital ini yang paling Anda sukai? Mengapa?

Peserta 1: Itu menjawab bagian pertanyaan dalam video karena saya lebih mengerti ketika ada pertanyaan dan jawabannya di video sehingga saya tahu apa yang harus saya jawab seperti penutur asli.

Peserta 2: Bagian yang saya sukai di buku digital adalah ketika kami belajar sambil mendengarkan cerita (percakapan mungkin) yang diceritakan dengan jelas melalui video.

Peserta 3: Bagian dialog karena dapat langsung dipraktikkan dan tidak membosankan.

e. Apakah Anda setuju dengan pernyataan bahwa buku teks digital dapat meningkatkan kemampuan bahasa Inggris Anda daripada yang tradisional?

Peserta 1: Ya, saya setuju karena saya bisa langsung mempraktikkan apa yang saya lihat di video dalam hal berbicara dan tata bahasa.

Peserta 2: Ya, saya setuju karena buku digital sangat bagus untuk mempertajam kemampuan bahasa Inggris.

Peserta 3: Ya, saya sangat yakin.

Berdasarkan hasil wawancara dengan para peserta, semua peserta berpikir bahwa buku teks digital bermanfaat, menarik dan bagus untuk pembelajaran bahasa Inggris mereka. 
Mereka juga berbagi pendapat yang sama dalam hal bagian paling favorit dalam buku digital yaitu bagian audiovisual di mana mereka mendapatkan model nyata dan penjelasan dari setiap pertanyaan. Hanya ada satu orang yang diwawancarai menyatakan bahwa dia lebih suka buku cetak karena dia tidak terbiasa dengan itu dan dia merasa sulit untuk menggunakan laptop karena ketersediaan colokan listrik di kelas tidak cukup memadai. Namun, semua peserta setuju bahwa buku teks digital dapat meningkatkan kemampuan bahasa Inggris Anda daripada yang tradisional.

Segera setelah wawancara untuk para peserta selesai, wawancara untuk dosen dilakukan secara langsung. Ada lima pertanyaan untuk setiap orang yang diwawancarai. Wawancara dilakukan setelah perawatan dalam kelompok eksperimen selesai. Berikut adalah hasil wawancara peserta:

Sebuah. Apa pendapat Anda tentang buku teks digital ini untuk kelas ELT Anda?

Ini sangat baik untuk murid-murid saya. Ini mudah digunakan karena pengguna bisa mengklik apa yang ingin mereka lihat atau dengar. Juga, itu menarik perhatian pelajar saya.

b. Apakah Anda lebih suka buku teks digital daripada kertas dalam mengajar? Mengapa?

Saya lebih suka menggunakan yang digital karena semua yang saya butuhkan dalam pengajaran seperti audio, video, gambar, dll dapat langsung ditemukan dalam aplikasi dengan hanya mengklik simbol.

c. Apakah Anda menemui kesulitan menggunakan buku digital ini dalam mengajar?

Sejauh ini, saya merasa agak sulit digunakan di awal karena saya harus membantu siswa saya secara individual dalam menginstal aplikasi dari DVD ROM karena beberapa dari mereka tidak memiliki kemampuan teknologi tinggi.

d. Bagian mana dari buku teks digital ini yang paling disukai siswa Anda? Mengapa?

Bagian terakhir dari setiap unit karena saya dapat menunjukkan beberapa video untuk memberikan contoh nyata berbahasa Inggris dari orang-orang di seluruh dunia dan memberikan mereka latihan dan siswa saya juga merasa senang dan senang.

e. Apakah Anda setuju dengan pernyataan bahwa buku teks digital dapat meningkatkan kemahiran bahasa Inggris siswa Anda daripada yang tradisional?

Ya, saya sangat setuju karena berdasarkan pengalaman saya siswa saya mendapatkan model nyata dan sumber belajar otentik. 
Berdasarkan wawancara dengan dosen yang mengajar kelompok eksperimen, menggunakan buku teks digital membantunya dalam mengajar karena mudah digunakan dan dapat menarik perhatian pembelajarnya dalam belajar. Dia juga lebih suka buku digital karena menyediakan materi lengkap dalam satu aplikasi dan murid-muridnya sebagian besar suka bagian video dalam buku. Dia hanya mengalami satu kesulitan di awal kelas ketika siswa harus menginstal buku di laptop mereka untuk pertama kalinya. Namun, dia setuju menyatakan bahwa buku teks digital dapat meningkatkan kemahiran bahasa Inggris siswa Anda daripada yang tradisional karena berdasarkan pengalamannya siswanya mendapatkan model nyata dan sumber belajar otentik.

Diskusi

Hasil analisis data dengan jelas mengungkapkan bahwa pemanfaatan buku teks digital di kelas bahasa Inggris efektif untuk meningkatkan kemahiran bahasa Inggris peserta didik. Temuan ini mengkonfirmasi hasil beberapa penelitian sebelumnya yang menemukan bahwa buku teks digital mampu mempromosikan keterampilan afektif peserta didik dan meningkatkan prestasi mereka dalam belajar (Choi, 2005, hal. 4877; Pearson, 2014, hal. 4; Rockinson-Szapkiw, Courduff, Carter, \& Bennett, 2013, hlm. 264). Itu dikonfirmasi oleh hasil prestasi akademik peserta didik dalam studi yang menunjukkan bahwa peserta didik yang menggunakan buku teks digital berkinerja lebih baik bahkan lebih baik daripada mereka yang menggunakan buku cetak. Choi (2005) berpendapat bahwa buku teks digital harus sesuai dengan karakteristik kursus atau pelajaran. Karena setiap pelajaran memiliki karakteristiknya sendiri seperti pelafalan dan pelajaran berbicara yang akan lebih baik jika buku teks digital menyertakan audio sebagai model untuk peserta didik. Juga, menambahkan beberapa fitur multimedia akan menguntungkan peserta didik, misalnya menambahkan audio atau video. Ini untuk memberikan bahan dan pengalaman otentik bagi siswa. Selain itu, buku teks digital akan jauh lebih baik jika juga menyertakan materi tambahan di mana peserta didik dapat membentuk soft skill mereka seperti pemecahan masalah, kerja tim, dll.

Lebih lanjut, Chau (2008, p. 4) menemukan bahwa aplikasi buku teks digital juga dapat mengembangkan literasi dan pengembangan bahasa peserta didik. Rockinson-Szapkiw, et. al (2013, p. 260) berpendapat bahwa membaca di buku teks digital bertahan lebih lama secara konsisten daripada buku-buku tradisional atau cetak. Namun, perkembangan teknologi memungkinkan pengembang untuk menambahkan teks dan 
fitur yang dapat diatur ulang yang kemudian diharapkan menghilangkan potensi kerugian dari buku teks digital.

Juga, peserta didik yang menggunakan buku teks digital ditemukan memiliki psikomotorik yang lebih baik dan belajar lebih efektif (Rockinson-Szapkiw, et. Al (2013, p. 264). Karena ketika peserta didik belajar menggunakan buku teks digital, mereka harus berinteraksi dengan menyentuh beberapa tombol. memainkan fitur dalam buku teks digital. Reints (2015) menjelaskan bahwa buku teks digital memungkinkan peserta didik tidak hanya memiliki pengalaman visual tetapi juga pengalaman audio dan audiovisual. Kemudian, buku teks digital juga dapat disesuaikan.

Selain itu, peserta didik yang belajar menggunakan buku teks digital menunjukkan sikap yang sangat positif terhadap pembelajaran (Rockinson-Szapkiw, et. Al (2013, p. 264). Oleh karena itu, ketika ada pernyataan bahwa buku teks digital dapat meningkatkan prestasi siswa, itu sangat masuk akal untuk percaya karena sikap positif mereka terhadap buku teks digital memengaruhi prestasi akademik mereka. Sebuah studi yang dilakukan oleh Torey Jones dan Carol Brown (2011 dikutip dalam Regueira \& Rodríguez, 2015) mencoba untuk mengetahui preferensi siswa setelah melakukan perawatan, memberi mereka tugas menggunakan buku teks digital dan cetak buku teks, kepada siswa .Hasil terbukti fakta menarik bahwa setelah memiliki pengalaman belajar dengan buku teks digital dan cetak, peserta didik cenderung lebih memilih yang digital karena menyediakan fitur pengucapan, audio, dll. Preferensi siswa mungkin terpengaruh oleh keakraban mereka dengan komputer, tablet dan smartphone seperti diketahui bahwa perangkat elektronik sangat populer di kalangan pelajar ners. Oleh karena itu, penggunaan buku teks digital memiliki potensi yang sangat menjanjikan untuk pendidikan karena meningkatnya minat digital di seluruh dunia (Misra, 2015).

Berdasarkan penjelasan, hasil penelitian ini mengkonfirmasi studi sebelumnya yang setuju bahwa menggunakan buku teks digital di kelas ESL bisa sangat efektif untuk meningkatkan prestasi belajar siswa. Selanjutnya, peserta didik dapat mengembangkan keterampilan literasi dan komunikasi mereka. Juga, pembelajaran yang efektif dapat dicapai melalui pembelajaran menggunakan buku teks digital.

Dalam penelitian ini, semua responden dalam wawancara memiliki pendapat yang sama tentang bagian yang paling disukai dari buku teks digital yaitu audiovisual di mana mereka dapat menemukan audio dan video. Ini mengkonfirmasi temuan dari studi 
sebelumnya yang dilakukan oleh Ødegård (2017, hal. 74) yang mengungkapkan bahwa fitur ini menguntungkan.

Mereka juga menunjukkan bahwa buku teks digital dapat memotivasi mereka dalam belajar karena buku itu menyenangkan dan menarik untuk digunakan. Pernyataan ini dikonfirmasi oleh kuliah mereka yang menyebutkan bahwa motivasi peserta didik juga meningkat selama penggunaan buku teks digital di kelas. Pearson (2014, p. 5) menemukan bahwa motivasi siswa yang menggunakan buku teks digital konsisten sampai akhir tahun sekolah sedangkan mereka yang menggunakan buku cetak memiliki motivasi belajar yang menurun. Regueira dan Rodríguez (2015) menemukan alasan mengapa peserta didik termotivasi oleh buku digital adalah karena itu mudah diakses dalam situasi apa pun. Kondisi ini ditemukan terkait dengan prestasi belajar mereka

\section{KESIMPULAN}

Kesimpulannya, pemanfaatan teknologi terbaru, dalam hal ini buku teks digital, telah membawa hasil yang efektif. Penelitian ini menegaskan bahwa menggunakan buku teks digital secara signifikan efektif untuk meningkatkan prestasi bahasa Inggris pembelajar ESL. Penelitian ini menemukan seberapa efektif penerapan buku teks digital itu dan bagaimana sikap atau tanggapan peserta didik dan guru (dosen bahasa Inggris dalam penelitian ini) terhadap pemanfaatan buku teks digital. Studi ini mengungkapkan bahwa buku teks digital dapat mempromosikan pencapaian pelajar dalam pembelajaran bahasa Inggris. Lebih jauh, fakta bahwa buku teks digital juga melibatkan pelajar untuk belajar karena terbukti dapat meningkatkan motivasi peserta didik untuk terus belajar.

\section{UCAPAN TERIMA KASIH}

Para peneliti ingin menyampaikan terima kasih kepada Kementerian Riset dan Pendidikan Tinggi Republik Indonesia atas dukungan penuh pada penelitian ini.

\section{REFERENSI}

Bikowski, D. \&Casal, J. E. (2018). Interactive Digital textbook and engagement: A learning strategies framework. Language Learning \& Technology Journal, 22(1), 119-136. ISSN 1094-3501. Retrieved from http://litjournal.org//

Blazer, C. (2013). Literature Review: Digital Textbooks. Research Services of MiamiDade County Public Schools. Retrieved from http://drs.dadeschools.net/ 
Carr, J. C. \& Maguire G. (2012).SpeakOut Starter Teacher's Resource Book. Essex: Pearson.

Charalambous, A. C. (2011). The role and use of course books in EFL. ERIC Journal. Retrieved from http://files.eric.ed.gov//

Chau, M. (2008). The effects of electronic books designed for children in education. Design of Electronic Text, 1(1), 1-4. Retrieved from https://tspace.library.utoronto.ca

Choi, J. (2005). The effect of digital textbook on academic achievement in Korea.Journal of Theoretical and Applied Information Technology, 95(18), 48714878. ISSN: 1992-8645. Retrieved from www.jatit.org.

Fernandes, L. (2011). Digital textbook platforms: Trends and technologies. Proceeding of II CongressoInternacional TIC Educacao, 3191-3211. Retrieved from http://ticeduca.ie.ul.pt//

Gak, Dragana, M. (2011).Textbook- An important Element in the teaching process.Fakultettehničkihnauka - Engleskijezik, Novi Sad, 78-82. Retrieved from http://epub.ff.uns.ac.rs//

Graves, K. (2000). Designing Language Course: A Guide for Teachers. Boston: Cengage Learning.

Hornby, A. S. (2006). Oxford Advanced Learners Dictionary (7th ed.). Oxford, UK: Oxford University Press.

Kaur, A. \& Kumar, R. (2015).Comparative analysis of parametric and non-parametric tests.Journal of Computer and Mathematical Sciences, 6(6), 336-342. ISSN 23198133 (Online).Retrieved from www.compath-journal.org.

MindCet. (2012). The future of digital textbooks. Ed-Tech innovation center. Retrieved from www.mindcet.org

Misra, P. K. (2015). Digital textbooks in India: Emergence, promotion and future predictions. In J. R. Rodriguez, E. Bruillard\& M. Horsley (eds.) Digital Textbooks: What's New?,101-111. Universidade de Santiago de Compostela.Retrieved from www.http://laeremiddel.dkk.

Mitsikopoulou, B. (2014). Digital enrichment of EFL textbooks.ResearchGate Journal, 404-430 Retrieved from https://www.researchgate.net/publication/283290226

Murray, M. C. \& Perez J. (2011). E-Textbooks are coming: Are we ready? Informing Science and Information Technology Journal, 8: 49-60.Retrieved from http://digitalcommons.kennesaw.edu// 
Ødegård, A. (2017). The use of digital textbooks in upper secondary school English classrooms in Norway.(Master's thesis). Retrieved from http://brage.bibsys.no//

Pearson Education.2014. Monroe Township High School Case Study.Retrieved from www.pearsoned.com.

Radić-Bojanić, B.B. \&Topalov, J.P. (2016). Textbooks in the EFL Classroom: Defining, assessing and analyzing. Collection of Papers of the Faculty of Philosophy XLVI (3).University of Novi Sad DOI:10.5937/ZRFFP46-12094

Reints, A. J. C. (2015). How to learn from digital textbooks: Evaluating the quality. In J. R. Rodriguez, E. Bruillard\& M. Horsley (eds.) Digital Textbooks: What's New?, 204-224. Universidade de Santiago de Compostela.Retrieved from www.http://laeremiddel.dk

Regueira, N. R. \& Rodríguez, J. R. (2015).The digital textbook.A look at the current state of the art. In J. R. Rodriguez, E. Bruillard\& M. Horsley (eds.) Digital Textbooks: What's New?,20-43. Universidade de Santiago de Compostela.Retrieved from www.http://laeremiddel.dk.

Richards, J. (2015). The Role of Textbooks in a Language Program. Retrieved from https://www.researchgate.net/publication/265455920

Rockinson- Szapkiw, A. J., Courduff, J., Carter, K., \& Bennett, D. (2013). Electronic versus traditional print textbooks: A comparison study on the influence of university students' learning. Computers \& Education, 63, 259-266. Retrieved from www.elsevier.com/locate/compedu

Sprent, P. \&Smeeton, N. C. (2001).Applied Nonparametric Statistical Method. Florida, USA: Chapman \& Hall/CRC 